Original Article

\title{
Awareness and Practice of Road Safety Rules among Secondary School Studentsin Jaipur, Rajasthan
}

\section{Maharaj Singh}

Associate Professor, Department of Paediatric Nursing, NIM S Nursing College, NIM SUniversity, Shoba Nagar, Jaipur-Delhi highway, (NH-11C), Jaipur-303121, Rajasthan, India.

Corresponding Author: Maharaj Singh, Associate Professor, Department of Paediatric Nursing, NIM SNursing College, NIM S University, Shoba Nagar, Jaipur-Delhi highway, (NH-11C), Jaipur - 303 121, Rajasthan, India.

Mobile : +919888166279 E-mail : maharaj2009@yahoo.com

Received

: 11.09 .2017

Review Completed : 14.12.2017

Accepted

: 05.05.2018

Keywords : Awareness, Practice, Road safety rules, Secondary school students

\begin{tabular}{|c|}
\hline Access this article online \\
\hline Quick Response Code \\
\hline
\end{tabular}

\begin{abstract}
:
Introduction: M ore than 1.2 million people die each year on the world's roads. M ost of these deaths are in low- and middle-income countries where rapid economic growth has been accompanied by increased motorization and road traffic injuries. Prevention of road traffic accidents thus becomes very crucial in order to improve the longevity and the quality of life of the individualsconcerned.
\end{abstract}

Objectives: To assess the level of awareness and practice of road safety rules among secondary school students.

\begin{abstract}
M ethods: A cross sectional study was conducted among 150 secondary school students aged between 13-17 years studying in selected government and private secondary schools of Achrol, Jaipur district, Rajasthan. The samples were selected through simple random sampling technique. A pre-designed and pre-tested structured multiple choice questionnaire and checklist was used for assessment of awareness and practice of road safety rules. The collected data was analysed by using descriptive and inferential statistics.
\end{abstract}

Results: With regardsto awareness regarding road safety rules, $9(6 \%)$ had had poor awareness, 103(68.7\%) had average awareness and 38(25.3\%) had good awareness. With regards to practice regarding road safety rules, $6(4 \%)$ had had unsatisfactory practice, $108(72 \%)$ had partially satisfactory practice and $36(24 \%)$ had satisfactory practice.

Conclusion : Majority of secondary school students had average awareness and partially satisfactory practice regarding road safety rules. Education reminding and strict enforcement of traffic rules can increase awareness and motivate them to strictly adhere to the traffic norms and help to reduce the morbidity and mortality due to road traffic accidents.

\section{Introduction}

\section{India is a global leader of deaths in road accidents!}

Road Traffic Accident can be defined as "An event that occurs on a way or street open to public traffic resulting in one or more persons being injured or killed, where at least one moving vehicle is involved". ${ }^{1}$ Road accidents are an outcome of the interplay of various factors, some of which are ignorance, carelessness, thoughtlessness, over confidence, length of road network, vehicle population and human population etc. Road accident causes injuries, fatalities, disabilities and affects children's growth and development. ${ }^{2}$
According to the global status report on road safety 2015 reflecting information from 180 countries, indicates that worldwide the total number of road traffic deaths has plateaued at 1.25 million per year with millions more sustaining serious injuries and living with long-term adverse health consequences. Globally, road traffic crashes are a leading cause of death among young people, and the main cause of death among those aged 15-29 years and second leading cause of death in 10-14 years and 20-24 years age groups. M otorcycle crashes are the leading cause of mortality and morbidity among teenagers. Road traffic injuries are currently estimated to be the ninth leading cause of death across all age groups globally, and are 
predicted to become the seventh leading cause of death by $2030 .{ }^{3}$

Road traffic death rates in low and middle income countries are more than double in comparison with high income countries. Worldwide, India has the worst road traffic accident rate, where every day about 1,374 accidents and 400 deaths take place, which have earned a dubious distinction with over 1,30,000 deaths annually. In terms of absolute numbers, highest number of deaths had taken place in Uttar Pradesh $((17,666)$, and Rajasthan $(10,510)$ had ranked fifth in the country. About 54.1 percent of all persons killed in road accidents are in the age group of 15 34 years. ${ }^{4}$

As per May 2017 report released by Dainik Bhaskar in Rajasthan, every year 10,000 people die due to road accidents. Among them 35\% are motorcycle riders. This year till March 2017, 2564 people died in road accidents. Among them highest number of deaths are from Jaipur North, Jaipur South, Hanumangarh, Bundi Bara, Chittorgarh and Pali district. In comparison with 2016 report, there is a rise of $83 \%$ in deaths in Hanumangarh and $71 \%$ in Jaipur North. This is an alarming sign, because either people do not have awareness regarding road safety rules ordo not obey the traffic rules. ${ }^{5}$

The United Nations has rightly proclaimed 2011-20 as the Decade of Action on Road Safety. India is a signatory to Brasilia Declaration and is committed to reduce the number of road accidents and fatalities up to 50 percent by 2020. Simple measures like awareness and practice of road safety measures can effectively reduce the impact of RTAs on the lives of people. ${ }^{6}$. Hence, the present study aimed to assess the awareness and practice of road safety rules among secondary school students in Jaipur, Rajasthan so that a better overview of the situation can be made.

\section{Materials and Methods}

This was a quantitative non-experimental study with cross sectional survey design conducted in the month of April 2017 among secondary school students of Achrol, Jaipur District of Rajasthan. The sample size was calculated based on the pre interventional knowledge on road safety rules and regulations $(p=54 \%)$ in a study among School Going Teenagers in Indore by Mahawar $\mathrm{P}$ et al [7] using the formula $\mathbf{N}=$ [Z1- (a/ 2) $\mathbf{2} \mathbf{~ p q}$ ] $/ \mathbf{d} \mathbf{2}$ and was derived as 150 . (Cl- $95 \%, d=10 \%$ of $p, 10 \%$ non-response rate). The study subjects were selected by two-stage stratified sampling method. One government and one private secondary school were selected from Achrol, in Jaipur North Region by lottery method to provide a representative sample. 75 students from the student lists of 9 th and $10^{\text {th }}$ class were selected randomly. The inclusion criteria for sample selection included: male and female students of $9^{\text {th }}$ and $10^{\text {th }}$ class in the age group of 13 to 17 years. The exclusion criteria included: Students who were suffering with some form of disability and were not willing to participate in the study. The study protocol was approved by institutional review board and institutional ethical committee of NIM S University, Jaipur, Rajasthan, India.

A pre-designed and pre-tested structured questionnaire was used for data collection and it consisted of three sections. Section A: Socio-demographic variables of secondary school students: It consisted of 9 variables including class, gender, residential area, father education, mother education, source of information, and mode of travelling to school. Section B: Structured awareness questionnaire, to assess awareness of road safety rules among secondary school students. It consisted of 40 items related to various aspects of road safety rules i.e. traffic signals, road safety laws and road sign's. Each item was carrying a score of one for correct answer and a score of zero for wrong answer. The awareness score was arbitrarily classified in to three categories viz. poor awareness (0-13), average awareness (14-26) and good awareness (27-40). Section C: Structured practice checklist, to assess practices of road safety rules among secondary school students. It consisted of 10 items related to various aspects including use zebra crossing to cross the roads, obey road traffic rules and signs, wear helmet/seatbelt while travelling, cross the road when vehicle are at a safe distance etc. Each item was carrying a score of one for presence of practice and a score of zero for absence of practice. The practices 
score was arbitrarily classified in to three categories viz. unsatisfactory practice (0-3), partial satisfactory practice (4-6) and satisfactory practice (7-10). The tool was translated in to Hindi and tested by back translation into English. The content validity of tool was obtained from the six experts in the field of medicine and nursing. The reliability co-efficient of awareness questionnaire was found to be $r=0.88$ by split half method and the reliability co-efficient of practice checklist was found to be $r=1$ by cronbach's alpha method. Hence tool was considered reliable for data collection.

To execute the study, the researcher obtained official written permission from Principals of selected secondary schools and written informed assent/consent from study sample and their parents after explaining the study purpose and assuring for confidentiality and anonymity. The data were collected through structured self administered questionnaire. The collected data were tabulated and analyzed in accordance with objectives of the study by using descriptive and inferential statistics with the help of Statistical Package for the Social Sciences version 16 software (SPSS Inc., Chicago, IL, USA) and Instat.

\section{Results}

The findings of the present study are discussed under the following headings:

Section I: Distribution of secondary school students according to their socio- demographic characteristics

The analysis of socio-demographic characteristics of secondary school students presented in table 1 shows that equal numbers of students (i.e.50.0\%) were taken from $9^{\text {th }}$ and $10^{\text {th }}$ class. Majority of students $(57.3 \%)$ were male. Majority of the students (68\%) were residing in urban area. Almost one third of the students fathers were educated up to higher secondary (32\%) and primary (29.3\%) level. Almost half of the students (44\%) mothers were educated up to primary level. M aximum numbers of students fathers were serviceman (65.3\%) and mothers were house wife $(62 \%)$. M aximum one third of the students (32\%) acquired the information regarding road safety rules through multiple sources i.e. through television, newspaper and textbooks. Maximum numbers of students (40.0\%) were coming to school through bicycles.

Section II: Description of level of awareness and practice regarding road safety rules among secondary school students:

The study findings of awareness regarding road safety rules among secondary school students revealed that 9(6\%) had had poor awareness, 103(68.7\%) had average awareness and $38(25.3 \%)$ had good awareness. The mean and standard deviation of the awareness score regarding road safety rules was $23.6 \pm 3.46$. The item wise awareness regarding road safety rules is depicted in table 2 .

The study findings of practice regarding road safety rules among secondary school students revealed that $6(4 \%)$ had had unsatisfactory practice, 108(72\%) had partially satisfactory practice and $36(24 \%)$ had satisfactory practice. The mean and standard deviation of the practice score regarding road safety rules was $5.86 \pm 0.96$. The item wise practice regarding road safety rules is depicted in table 3 .

Section III: correlation between awareness and practice score of road safety rules among secondary school students:

The correlation between awareness and practice score of road safety rules revealed that there was a significant positive correlation ( $r=0.334, p<0.001)$ between awareness and practice, which indicates that as awareness level increases practice level also increases.

Section IV: Relationship of awareness and practice score of road safety rules with selected socio-demographic variables of secondary school students:

The study result of relationship between awareness of road safety rules and selected socio-demographic variables of secondary school students showed that residential area ( $t=2.13 p=0.05)$, father education ( $t=2.26 p=0.05$ ), mother education( $t=2.42 p=0.01$ ) and source of information ( $t=$ $2.98 p=0.01$ ) had a significant relationship with awareness score of secondary school students. 
As well as the study result of relationship between practice of road safety rules and selected socio-demographic variables of secondary school students showed that father education ( $t=2.31 \mathrm{p}=0.05)$, mother education $(\mathrm{t}=2.38$ $p=0.01)$ and source of information ( $t=2.87 p=0.01)$ had a significant relationship with practice score of secondary school students.

Table 1 : Frequency and percentage distribution of secondary school students according to their socio- demographic characteristics $\mathrm{N}=150$

\begin{tabular}{|c|c|c|c|}
\hline Sr. No. & Socio-demographic variables & $\mathrm{n}$ & $\%$ \\
\hline A & Class & & \\
\hline 1. & $9^{\text {th }}$ & 75 & $50 \%$ \\
\hline 2. & $10^{\text {th }}$ & 75 & $50 \%$ \\
\hline$B$ & Gender & & \\
\hline 1. & Male & 86 & 57.3 \\
\hline 2. & Female & 64 & 42.7 \\
\hline $\mathrm{C}$ & Residential area & & \\
\hline 1. & Rural & 48 & 32 \\
\hline 2. & Urban & 102 & 68 \\
\hline $\mathrm{D}$ & Father education & & \\
\hline 1. & Primary & 44 & 29.3 \\
\hline 2. & Secondary & 32 & 21.3 \\
\hline 3. & Higher Secondary & 48 & 32.0 \\
\hline 4. & Graduate \& Above & 26 & 17.4 \\
\hline$E$ & Mother education & & \\
\hline 1. & Primary & 66 & 44 \\
\hline 2. & Secondary & 42 & 28 \\
\hline 3. & Higher Secondary & 30 & 20 \\
\hline 4. & Graduate \& Above & 12 & 08 \\
\hline $\mathrm{F}$ & Father occupation & & \\
\hline 1. & Service & 98 & 65.3 \\
\hline 2. & Business & 32 & 21.3 \\
\hline 3. & Farmer & 20 & 13.4 \\
\hline G & Mother occupation & & \\
\hline 1. & Service & 42 & 28 \\
\hline 2. & House Wife & 93 & 62 \\
\hline 3. & Business & 15 & 10 \\
\hline $\mathrm{H}$ & Source of Information & & \\
\hline 1. & Television & 44 & 29.3 \\
\hline 2. & Newspaper & 26 & 17.3 \\
\hline 3. & Textbook & 32 & 21.4 \\
\hline 4. & All of above & 48 & 32.0 \\
\hline I & Mode of travelling to school & & \\
\hline 1. & Scooty / Motorcycle & 32 & 21.3 \\
\hline 2. & Pedestrians & 26 & 17.3 \\
\hline 3. & School Bus & 32 & 21.4 \\
\hline 4. & Bicycle & 54 & 40.0 \\
\hline
\end{tabular}

Table 2: Item wise awareness regarding road safety rules among secondary school students

\begin{tabular}{|c|c|c|c|}
\hline $\begin{array}{l}\text { Item } \\
\text { No. }\end{array}$ & Items & $\begin{array}{c}\text { Number with } \\
\text { correct } \\
\text { response }\end{array}$ & $\%$ \\
\hline 1. & Meaning of road traffic rules & 98 & 65.3 \\
\hline 2. & Red traffic signal indicates & 115 & 76.7 \\
\hline 3. & indicates & 35 & 23.3 \\
\hline 4. & $\begin{array}{l}\text { Right way for crossing the } \\
\text { road by Pedestrians. }\end{array}$ & 102 & 68 \\
\hline 5. & Legal age for driving a vehicle & 88 & 58.7 \\
\hline 6. & indicates & 78 & 52 \\
\hline 7. & Yellow traffic signal indicates & 110 & 73.3 \\
\hline 8. & $\begin{array}{l}\text { While crossing a road person } \\
\text { should always look }\end{array}$ & 85 & 56.7 \\
\hline 9. & indicates & 46 & 30.7 \\
\hline 10. & $\begin{array}{l}\text { Right approach to cross the } \\
\text { speed breaker with vehicle }\end{array}$ & 116 & 77.3 \\
\hline 11. & $\begin{array}{l}\text { Number of person can travel } \\
\text { on bike/ scooty }\end{array}$ & 109 & 72.7 \\
\hline 12. & indicates & 72 & 48 \\
\hline 13. & indicates & 73 & 48.7 \\
\hline 14. & $\begin{array}{l}\text { The side should be used by } \\
\text { pedestrians while walking on road }\end{array}$ & 140 & 93.3 \\
\hline 15. & indicates & 28 & 18.7 \\
\hline 16. & $\begin{array}{l}\text { While travelling on two or four } \\
\text { wheelers head injuries can be } \\
\text { prevented by the use of }\end{array}$ & 128 & 85.3 \\
\hline 17. & Safer speed limit of vehicle & 100 & 66.7 \\
\hline 18. & indicates & 80 & 54 \\
\hline 19. & indicates & 118 & 78.7 \\
\hline 20. & Green traffic signal indicates & 120 & 80 \\
\hline 21. & Indicator to be used & 71 & 47.3 \\
\hline 22. & liat & 28 & 18.7 \\
\hline
\end{tabular}




\begin{tabular}{|c|c|c|c|}
\hline $\begin{array}{l}\text { Item } \\
\text { No. }\end{array}$ & Items & $\begin{array}{c}\text { Number with } \\
\text { correct } \\
\text { response }\end{array}$ & $\%$ \\
\hline 23. & $\begin{array}{l}\text { Leading cause of road traffic } \\
\text { accidents }\end{array}$ & 128 & 85.3 \\
\hline 24. & indicates & 82 & 54.7 \\
\hline 25. & Bright dippers are always used at & 99 & 66 \\
\hline 26. & indicates & 48 & 32 \\
\hline 27. & $\begin{array}{l}\text { The city where traffic rules } \\
\text { are mostly followed }\end{array}$ & 100 & 66.7 \\
\hline 28. & indicates & 72 & 48 \\
\hline 29. & indicates & 76 & 50.7 \\
\hline 30. & $\begin{array}{l}\text { Recommended colour for head } \\
\text { lights of vehicle }\end{array}$ & 98 & 65.3 \\
\hline 31. & indicates & 73 & 48.7 \\
\hline 32. & $\begin{array}{l}\text { Recommended intensity of } \\
\text { the horn }\end{array}$ & 88 & 58.7 \\
\hline 33. & indicates & 85 & 56.7 \\
\hline 34. & Right direction of focusing headlight & 88 & 58.7 \\
\hline 35. & indicates & 92 & 61.3 \\
\hline 36. & $\begin{array}{l}\text { The way safety belt protect } \\
\text { the person }\end{array}$ & 120 & 80 \\
\hline 37. & indicates & 52 & 34.7 \\
\hline 38. & $\begin{array}{l}\text { Right way of crossing one } \\
\text { vehicle by another }\end{array}$ & 49 & 32.7 \\
\hline 39. & indicates & 45 & 30 \\
\hline 40. & The sign " $\mathrm{L}$ " on car indicates & 107 & 71.3 \\
\hline
\end{tabular}

\section{Discussion}

Road safety awareness is one of the most important aspects towards safety concerning traffic rules among adolescent children. Adolescent age group is rapidly emerging as a major population of vehicle owners and may derive a thrill out of taking risks on road without realizing
Table 3: Item wise practices regarding road safety rules among secondary school students $\mathrm{N}=150$

\begin{tabular}{|c|l|c|c|}
\hline $\begin{array}{c}\text { Item } \\
\text { No. }\end{array}$ & Items & $\begin{array}{c}\text { Number of } \\
\text { participants } \\
\text { who practice }\end{array}$ & \\
\hline 1. & Use zebra crossing to cross the roads & 97 & 64.7 \\
\hline 2. & Obey road traffic rules and signs & 106 & 70.7 \\
\hline 3. & $\begin{array}{l}\text { Wear seatbelt when travelling in a } \\
\text { four wheeler }\end{array}$ & 62 & 41.3 \\
\hline 4. & $\begin{array}{l}\text { While crossing the road avoid } \\
\text { talking/reading }\end{array}$ & 65 & 43.3 \\
\hline 5. & $\begin{array}{l}\text { Wear helmet when travelling } \\
\text { on a two wheeler }\end{array}$ & 68 & 45.3 \\
\hline 6. & $\begin{array}{l}\text { Look left, right and left again } \\
\text { before crossing a road/street. }\end{array}$ & 102 & 68 \\
\hline 7. & Watch for turning vehicles & 140 & 93.3 \\
\hline 8. & $\begin{array}{l}\text { Cross the road when vehicles } \\
\text { are at a safe distance. }\end{array}$ & 138 & 92 \\
\hline 9. & $\begin{array}{l}\text { Always walks on the right } \\
\text { side of road }\end{array}$ & 68.7 \\
\hline 10. & $\begin{array}{l}\text { Stay on the footpath at earmarked } \\
\text { bus stoppage. }\end{array}$ & 124 \\
\hline
\end{tabular}

the consequences, hence it is very important to assess awareness and practice on road safety rules and sensitize this population as they are future of the nation.

The findings of present study showed that majority of secondary school students i.e. $68.7 \%$ had average awareness and only $25.3 \%$ had good awareness. This finding is similar to the study conducted among school children in Indore, Chandigarh, Chennai and Guntur city. ${ }^{7-10}$ $65.3 \%$ of the students were aware about the traffic rules. This finding is consistent with findings of the study conducted among medical students in Barabanki, Utta Pradesh. ${ }^{11} 56.7 \%$ of the students were aware about the rules for pedestrians. This finding is contradictory to study conducted among medical students in Barabanki, Utta Pradesh where the awareness was high. ${ }^{11} 58.7 \%$ students knew the legal age for driving vehicles. This finding is similar with the studies conducted in Indore, Chandigarh, Guntur city and rural Tamil Nadu, whereas this was low as compared to study conducted among medical students in Barabanki, Utta Pradesh. ${ }^{7-8,} 10-1232.7 \%$ of students were aware about right way of overtaking. This finding is similar to the study conducted among school going students in Indore and Chandigarh. ${ }^{7.8}$ Almost half of the students were 
able to identify the road signs correctly. Similar findings were observed in the study conducted among high school students in Guntur city and rural area of Tamil Nadu, whereas good knowledge on road signs was observed among medical students in Barabanki, Utta Pradesh. ${ }^{11-12}$ Zebra crossing sign was known to half $(50.7 \%)$ of the students which was high as compared to study conducted in Chandigarh (39.5\%) and Indore (21\%), $76.7 \%$ and $73.3 \%$ of students had correct awareness of red and yellow traffic signals respectively, this awareness was much higher than the study conducted among school going teenagers in Indore. ${ }^{7}$

As per findings of the present study, majority of secondary school students i.e. $72 \%$ had partially satisfactory practice, $24 \%$ had satisfactory practice and $4 \%$ had unsatisfactory practice. These findings are contradictory with the findings of the study conducted among primary school children in Chennai where the road safety practice was very poor. ${ }^{9}$ $70.7 \%$ of the students reported that they obey road traffic rules and signs. This finding is almost consistent with the findings of the study conducted in Barabanki Utta Pradesh. ${ }^{11} 41.3 \%$ of the students wear seatbelt when travelling in a four wheeler and $45.3 \%$ of the students wear helmet during riding or travelling on two-wheelers. Such high risk taking behaviour among the study participants is alarming. These findings are consistent with the findings of the study conducted in Chandigarh and Guntur city. 8,10 While as these findings are contradictory with findings of the study conducted in Chennai and Chandigarh, where the practice of wearing helmet/seatbelt while travelling was high and in Barabanki, Utta Pradesh it was low. ${ }^{14-15,11} 43.3 \%$ of the students reported that they avoid talking/reading while crossing the road. This finding is consistent with the findings of the study conducted in Guntur, South India. ${ }^{10}$ and Saudi Arabia as well as contradictory with findings of

\section{References}

1. Transport Research Wing, Ministry of Road Transport and Highways. Road Accidents in India 2011. New Delhi: Ministry of Road Transport and Highways, Government of India; 2012. Available at URL: http:// www.jotr.in/article.asp. Accessed on 15 M arch 2017.

2. Transport Research Wing, Ministry of Road Transport and Highways. Road Accidents in India 2010. New Delhi: M inistry of Road Transport the study conducted in Barabanki Uttar Pradesh and Chandigarh where majority of students avoid talking on mobile phones. ${ }^{11,15}$

The findings of present study showed that there was a significant positive correlation $(r=0.334, p<0.001)$ between awareness and practice of road safety rules. This finding is consistent with the findings of study conducted among primary school children in Chennai. ${ }^{9}$

The present study result revealed that the awareness and practice regarding road safety rules had significant relationship with residential area, father education, mother education and source of information of secondary school students. The present study findings are consistent (source of information) as well as contradictory (age, education and mode of transport) with the findings of study conducted among primary school children in Chennai. ${ }^{9}$

\section{Conclusion}

The majority of secondary school students had average awareness and partial satisfactory practice; so there is a need to sensitize this population. Efforts should be made in improving this issue through inclusion of traffic chapter in syllabus of students, re-orientation training, signboards, posters and mass media. Strict enforcement of laws and periodic organization of traffic awareness campaigns and practice relating to road safety should be encouraged to reduce the morbidity and mortality related to road traffic accidents.

\section{Acknowledgements}

The author expresses deep sense of gratitude and thanks to principal, faculty and children of Government secondary school, Achrol, Jaipur, and M arigold public school, Achrol, Jaipur, Rajasthan for granting permission and cooperation in conducting this study.

and Highways, Government of India; 2010. Available at URL: http://indiagovernance.gov.in. Accessed on $20 \mathrm{M}$ arch 2017.

3. World Health Organization. Global status report on road safety.2015. Available at URL: http://www.who.int/violence_injury prevention/road_safety_status/2015/en/. Accessed on $20 \mathrm{March}$ 2017. 
4. Transport Research Wing, Ministry of Road Transport and Highways. Road Accidents in India - 2015. New Delhi: M inistry of Road Transport and Highways, Government of India; 2015. Available at URL: http:// pibphoto.nic.in/documents/rlink/2016/jun/p20166905.pdf. Accessed on 10 April 2017.

5. Kataria GC, Home Minister Rajasthan. Report on road accidents in Rajasthan. Danik Bhaskar. M ay 08; 2017.

6. World Health Organization. Global plan for the decade of action for road safety, 2011-2020, Version 3. Available at URL: http://www.who.int/roadsafety/decade_of_action/plan/global_plan decade.pdf. Accessed on 25 April 2017.

7. Mahawar P. An education intervention to improve awareness on road safety: a study among school going teenagers in Indore. Natl J Community Med 2013; 4: 529- 32.

8. Swami HM, Puri S, Bhatia V. Road safety awareness and practices among school children of Chandigarh. Indian J Commun Med 2006; 31:199.

9. Thenmozhi P. Assess the knowledge and practice on road safety regulations among primary school children in rural community. SSRGIJMS2016; 3:1-5.
10. Dulipala P,Gujjarlapudi C. Awareness and practice of road safety measures among college going students in Guntur City. International Journal of M edical Research and Review 2016; 3: 1-5.

11. Zaidi Nawaz SZ, Paul Chandra P, M ishra P, Srivastava A. Risk perception and practice towards road traffic safety among medical students. Int J Community Med Public Health 2017; 4: 1-6.

12. Raj C, Datta S, Singh Z, VS. Study of knowledge and behavioural patterns with regard to road safety among high school children in a rural community in Tamil Nadu, India. Indian J M ed Spec 2011; 2: 1-5.

13. Mahawar P, Dixit S, Khatri AK, Rokade R, Bhurre R, Kirar S et al. An educational intervention to improve awareness on road safety: $A$ study among school going teenagers in Indore. National Journal of Community Medicine 2013; 4: 529-32.

14. Padankatti S, Narayan U, Babu JS, Thomas K. Road safety practices among school going children in Chennai. International Journal of Emergency M edicine 2014;7: 2.

15. Kumar M, Baweja M, Singh A, Sharma VL. Awareness and practice on road safety among students of Punjab University Chandigarh, India. Asian Journal of M ultidisciplinary Studies 2014; 2: 1-4. 